\title{
STE11 is a protein kinase required for cell-type-specific transcription and signal transduction in yeast
}

\author{
Nelson Rhodes, ${ }^{1}$ Laurie Connell, ${ }^{2,3}$ and Beverly Errede ${ }^{1,2,4}$ \\ ${ }^{1}$ Department of Chemistry and ${ }^{2}$ Genetics Curriculum, University of North Carolina, Chapel Hill, North Carolina 27599 USA
}

The STE11 gene of Saccharomyces cerevisiae is one of several genes required for mating between two haploid cell types of this yeast. Its product is required for response to a signal that causes arrest of the mitotic cell cycle in the $G_{1}$ phase and induction of mating-type-specific genes. The nucleotide sequence of the STE11 gene was determined. The predicted amino acid sequence shows homology to the protein kinase family. We demonstrate that the STE11 product has kinase catalytic activity and that this activity is required for its in vivo functions.

[Key Words: Protein kinase; yeast mating response pathway; gene expression; epitope-tagging]

Received June 22, 1990; revised version accepted August 28, 1990.

The yeast Saccharomyces cerevisiae is an experimentally accessible eukaryotic organism for the study of events controlling cell-type determination and cell communication. The a and $\alpha$ haploid cells of this yeast are able to mate with each other to form an $\mathbf{a} / \alpha$ diploid cell that is mating incompetent. Recognition between the a and $\alpha$ cell types initiates and coordinates events that are a precondition for cell fusion. This recognition is mediated by the peptide pheromones, a- and $\alpha$-factor, which are characteristic of each cell type and their respective receptors (for review, see Cross et al. 1988; Herskowitz 1989). The signal generated by the interaction between receptor and mating pheromone causes transcriptional induction of genes required for mating, as well as for arrest of the mitotic cell cycle in the $G_{1}$ phase.

It appears that all components necessary for the response elicited by pheromone-receptor binding are the same in both cell types (Bender and Sprague 1986; Nakayama et al. 1987). Genetic approaches to dissect the signal transduction pathway have led to the identification of several genes (GPA1/SCG1, STE4, STE5, STE7, STE11, STE12, STE18, and FUS3) that specify, directly or indirectly, components of the signal pathway (Hartwell 1980; Dietzel and Kurjan 1987; Miyajima et al. 1987; Jahng et al. 1988; Nakayama et al. 1988; Whiteway et al. 1989; Elion et al. 1990). Three of the genes (GPA1/ SCG1, STE4, and STE18) were found to encode proteins homologous to the $\alpha-, \beta$-, and $\gamma$-subunits of mammalian G protein (Dietzel and Kurjan 1987; Miyajima et al. 1987; Jahng et al. 1988; Whiteway et al. 1989). Various observations suggest a model for signal transmission in

3Present address: Massachusetts Institute of Technology, Cambridge, Massachusetts 02139 USA.

"Corresponding author. which pheromone binding to receptor promotes the exchange of GDP for GTP, resulting in dissociation of the $\beta, \gamma$-complex from the GTP bound $\alpha$-subunit. It appears that free $\beta, \gamma$-complex transmits the signal (Blinder et al. 1989; Cole et al. 1990; Nomoto et al. 1990; Whiteway et al. 1990). Little is known about the steps in the signal pathway after the G-protein, except that the STE12 transcription factor has been implicated as a possible nuclear target for the signal (Dolan et al. 1989; Errede and Ammerer 1989).

We have begun investigations to determine what function the STE11 product has in the pheromone response pathway. Mutation of the STE11 gene prevents mating and responses to pheromone, including arrest of the mitotic cell cycle in the $G_{1}$ phase and induction of cell-type-specific gene expression (Hartwell 1980; McCaffrey et al. 1987; Trueheart et al. 1987). The STE11 gene product is also required for basal expression from a cell-type-specific activator sequence (Errede et al. 1981). It has been difficult to place the point of action for STE11 in the signal pathway, because in its absence there is a reduction in the basal-level expression of the pheromones (15- to 100-fold), receptors (5-fold), and Gprotein $\alpha$-subunit (2-fold) (Fields et al. 1988; Nakayama et al. 1988). However, we can infer that its function is required for signal transmission after the G-protein because ste11 mutants block the constitutive $G_{1}$ arrest caused by loss of function of the G-protein $\alpha$-subunit (Nakayama et al. 1988). In this study we provide evidence of a STE11-dependent protein phosphorylation. This biochemical evidence supports the view that STE11 is a protein kinase. In vivo analysis of a STE11 catalytic residue substitution mutation supports the view that its kinase activity is required for its function in the mating response pathway. 


\section{Results}

\section{STE11 nucleotide sequence}

We determined the nucleotide sequence of the STE11 gene. The 3.1-kb HindIII-ClaI interval (Fig. 1A, a) from the plasmid pSTE11.1 was used for sequence determination (Chaleff and Tatchell 1985). We report 2578 nucleotides of sequence from this interval for which we have data on both strands (Fig. 2). The DNA sequence was translated in all six frames. The longest open reading frame (ORF) extends from position 32 to position 2266, where it terminates with a TGA translation termination codon. No consensus sequences for RNA splice sites in yeast were detected (Langford and Gallwitz 1983).

\section{STE11 mRNA}

The $5^{\prime}$ end of the STE11 mRNA was determined by S1 analysis. The major STE11 transcript maps to position 86 or 87 with minor transcripts mapping to positions 59

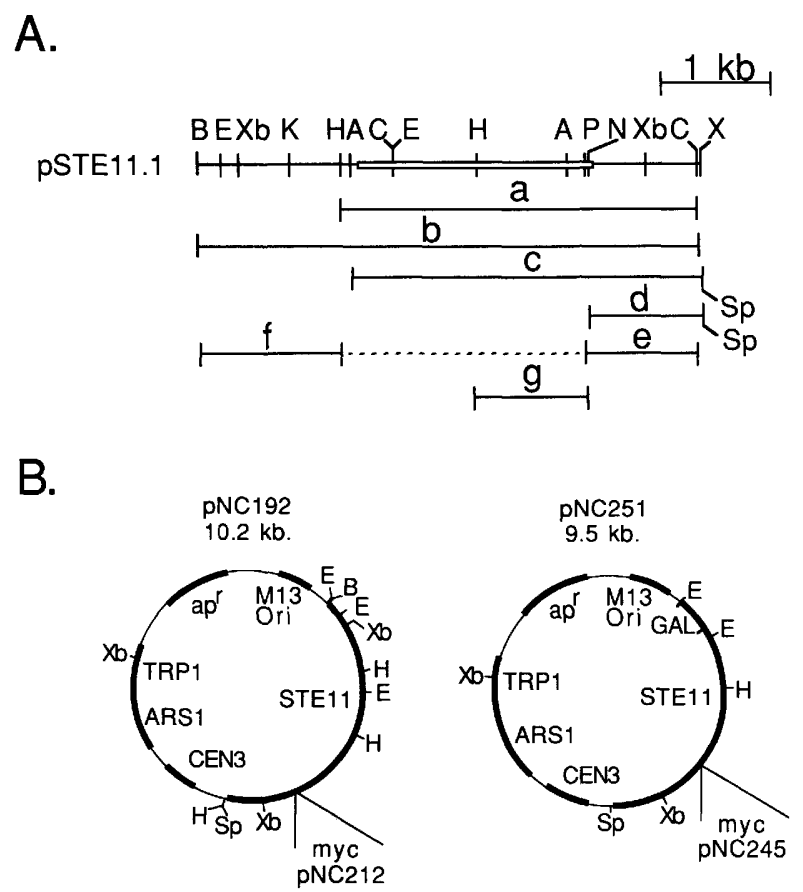

Figure 1. Representation of the STE11 locus and STE11 plasmids. (A) The 4.6-kb BamHI-XhoI fragment from pSTE11.1 is shown (Chaleff and Tatchell 1985). The open box delimits the STE11 protein-coding region. Bars indicate fragments a-g used to manipulate STE11 as described in the text. The SphI site indicated on bars $\mathrm{c}$ and $\mathrm{d}$ comes from polylinker sequences flanking STE11 in pNC192 or pNC251. (B) The plasmid pNC192 contains the STE11 gene and its own promoter. The plasmid pNC251 contains the STE11 gene under control of the GAL1,10 promoter. The ampicillin-resistance gene $\left\langle\mathrm{ap}^{\mathrm{r}}\right\rangle, \mathrm{M} 13$ origin of replication (M13 ori), and yeast components are indicated. The position of the myc epitope tag in plasmids pNC212 and pNC245 is also indicated. Restriction sites: (A) AccI; (B) BamHI; (C) ClaI; (E) EcoRI; (H) HindIII; (K) KpnI; (N) NcoI; (P) $P_{\text {st }}$; (Sp) SphI; (X) XhoI; (Xb) XbaI. or 60,68 or 69,91 or 92 , and 98 or 99 . The signal from the protected DNA probe was proportional to the amount of STE11+ RNA in the reaction (Fig. 3A, lanes 1 and 2). No signal was observed for reactions performed with RNA from the isogenic ste11 $\Delta$ strain (Fig. 3A, lane 3 ) or when RNA was absent from the nuclease digestion reactions (Fig. 3A, lane 4). We found no difference in $5^{\prime}$ map positions or abundance of STE11 mRNA prepared from either pheromone-treated ( $\alpha$-factor) cultures or untreated cultures (Fig. 3B). A TATA-box-like sequence (nucleotide positions $42-47$ ) is present 40 nucleotides upstream from the major mRNA $5^{\prime}$ map position. A sequence similar to the tripartite transcription termination control consensus sequence (TAG/TATGT/TTT) identified by Zaret and Sherman (1982) is present in the STE11 sequence between nucleotides 2352 and 2390 (Fig. 2). On the basis of the $5^{\prime}$ map position and the inferred $3^{\prime}$ end, the predicted STE11 transcription unit is close to the observed 2.4-kb size for the STE11 RNA (Chaleff and Tatchell 1985).

\section{STE11 translation product}

The STE11 ORF contains three ATG codons near the $5^{\prime}$ end (located at nucleotide positions 53,86 , and 116; Fig. 2). None of these occurs in a sequence context that is a good match to the consensus associated with translational initiator regions in yeast (Cigan and Donahue 1987). The 5' map positions of STE11 mRNAs made it possible that the ATG codons at positions 86 and/or 116 could be used for initiation of the STE11 primary translation product. Frameshift mutations were made to determine which of these codons is necessary for a functional STE11 product. The rationale for this approach is that a nucleotide insertion or deletion before the initiation codon should not cause a mutant phenotype, whereas an insertion or deletion after the initiation ATG should result in a ste11 null mutation.

Two frameshift mutations were made. One mutation was an insertion of a single thymidine after nucleotide position 100 (between ATG codons at positions 86 and 116). The other mutation was a deletion of a single guanine residue at nucleotide position 377 (after the ATG codon at position 116). Plasmids carrying the different STE11 frameshift mutations were used to transform a yeast strain with a complete ste11 deletion (E929-6C-5). Function of the different STE11 frameshift mutations was assessed by whether the transformed strains were able to mate with a suitable tester strain. A nucleotide inserted after the ATG at position 86 resulted in a STE11 product that is functional. In contrast, a single nucleotide deletion after the ATG at position 116 resulted in a nonfunctional ste11 allele. These results, together with the $5^{\prime}$ mRNA mapping experiments, are consistent with translation initiating from the first AUG in the major STE11 mRNA (Fig. 2). The STE11 translation product predicted in this case begins with the methionine coded for by the ATG at nucleotide position 116. The predicted STE11 protein is 717 amino acids in length with a calculated molecular size of 80 


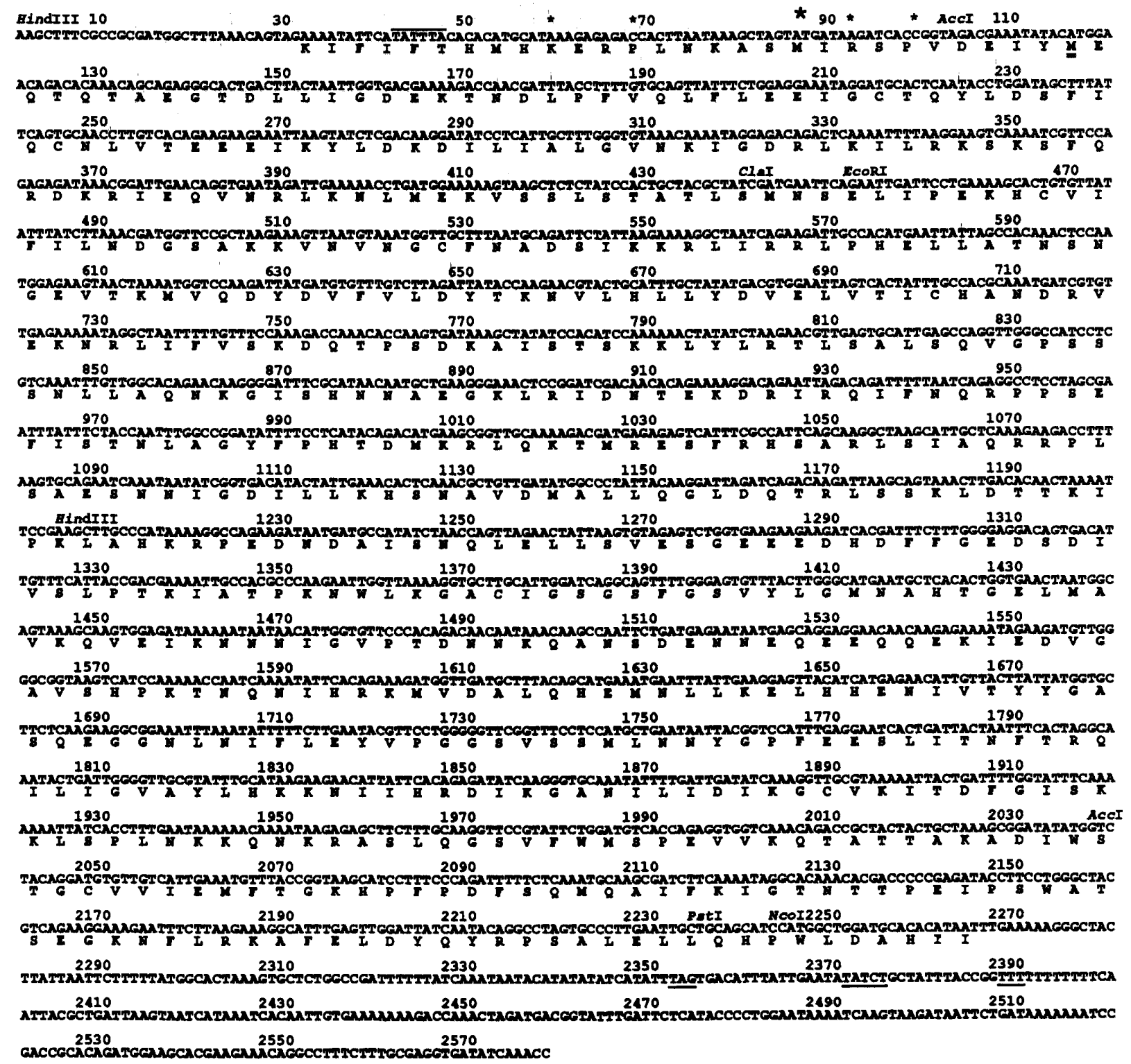

Figure 2. Nucleotide and predicted protein sequence of the STE11 gene. The nucleotide sequence of the coding strand is shown. The amino acid sequence for the complete ORF (nucleotide positions 32-2266) is shown below the nucleotide sequence. The initiating methionine (codon positions $116-118$ ) for the predicted protein is underlined. A consensus TATA element (TATTTA) at nucleotide positions $42-47$ is overlined. The $5^{\prime}$ map positions for the STE11 mRNA are denoted by asterisks ( ${ }^{*}$ ) above the nucleotide sequence at positions 59 or 60,68 or 69,86 or 87,91 or 92 , and 98 or 99 . The transcription termination control sequence (TAG/TATCT/TTT) between nucleotides 2352 and 2390 is underlined. Certain restriction sites are indicated: HindIII (positions 1 and 1205), AccI (positions 101 and 2038), ClaI (position 440), EcoRI (position 445), PstI (position 2234), and NcoI (position 2243).

$\mathrm{kD}$. These data do not indicate whether the AUG at position 86 could be used in the case of the minor mRNAs that map to nucleotide positions 59 or 60 and 68 or 69 . Even if this longer translation product is made, it is not an essential species for STE11 function because the frameshift mutation at nucleotide position 100 has no effect on mating ability. The position 100 frameshift mutation similarly rules out the possibility that a STE11 product initiating with the ATG codon at position 53 could be essential for mating.
The predicted STE11 protein is related to protein kinases

The FASTA algorithm of Pearson and Lipman (1988) was used to compare the predicted STE11 protein to the NBRF protein data base (Release 17, January 1989). The search revealed that the carboxy-terminal region (amino acid positions $413-717$ ) of the predicted STE11 protein shows striking homology to the catalytic domain of protein kinases. The STE1l kinase domain has the 15- 


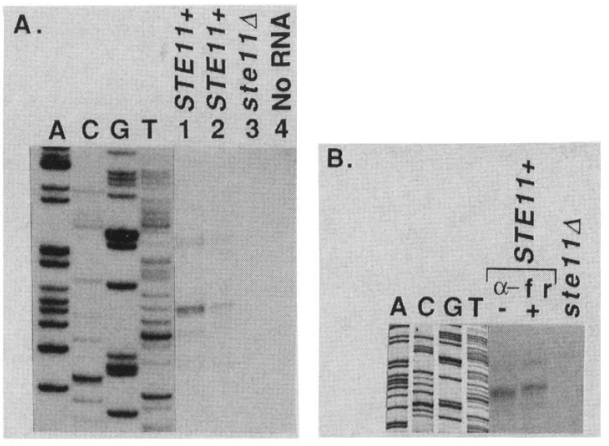

Figure 3. STE11 5' mRNA map positions as determined by $\mathrm{Sl}$ analysis. $(A)$ (Lanes 1 and 2) Protected products from S1 nuclease digestion reactions using $50 \mu \mathrm{g}$ and $20 \mu \mathrm{g}$ of total RNA from STE $11^{+}$strain E929-6C; (lane 3) control reaction using 50 $\mu \mathrm{g}$ of total RNA from ste11 $\Delta$ strain E929-6C-20; (lane 4) mock reaction with no RNA. RNAs were hybridized to the 200 -nucleotide probe prepared with oligonucleotide STE11.75 (Table 2). (B) (Lanes $S T E 11^{+}$) Protected products from Sl nuclease digestion reactions using $30 \mu \mathrm{g}$ of RNA isolated from cultures of STE1 $1^{+}$strain E929-6C either without $\alpha$-factor $(-)$ or after 2 -hr exposure to $5 \mu \mathrm{M} \alpha$-factor $(+)$; (lane ste11 $1 \Delta$ ) control reaction using $30 \mu \mathrm{m}$ of RNA prepared from ste11 1 strain E929-6C-5. RNAs were hybridized to the 1100 -nucleotide probe prepared with oligonucleotide STE11.18 (Table 2). Lanes $A, C, G$, and $T$ in $A$ and $B$ depict dideoxy sequencing products using either labeled oligonucleotide STE11.75 or STE11.18, respectively, as a primer and pNC193 DNA as template. These ladders show the nucleotide sequence of the noncoding strand.

amino-acid residues that are conserved in the catalytic domain for at least 62 of the 65 protein kinases compared by Hanks et al. (1988; Fig. 4). STE11 has amino acid sequences in subdomains VI (DIKGAN) and VIII (GSVFWMSPE) with high similarity to the sequences DLKPEN and GT/SXXY/PXAPE, respectively, which are indicators of the serine/threonine family of protein kinases (Hanks et al. 1988).

An alignment of the STE11 kinase catalytic domain was made with that of the three other predicted protein kinases (STE7, KSS1, and FUS3), which have roles in the mating response pathway (Fig. 4) (Teague et al. 1986; Courchesne et al. 1989; Elion et al. 1990). The alignment indicates that STE11 is not more closely related to this group than to other protein kinases. Outside of the 15 conserved residues characteristic of protein kinases, there are only 18 additional residues conserved among this group. STE11 is notably more similar to STE7 in the region of subdomains IV and V ( $38 \%$ identity) than to FUS3 or KSS1 (12\% identity to each). When the entire catalytic domain is compared, STE11 is not significantly more similar to STE7 than to the other kinases. For the catalytic domain overlap region of 255 amino acids, the STE11 protein showed $27 \%$ identity to STE7, $24 \%$ identity to FUS3, and $22 \%$ identity to KSS1. This is in contrast to the KSS1 and FUS3 protein kinases, which are more closely related to each other (54\% identity) than to other protein kinases.

\section{Immunological detection of STE11.}

We fused the coding sequence of a known epitope to the STE11 gene to allow detection of the STE11 product. The chosen epitope consisted of 10 amino acids from human c-myc for which a specific monoclonal antibody (Myc1-9E10) was available (Evan et al. 1985; Munro and Pelham 1987). An in-frame fusion of the epitope-coding fragment was made after codon 717 of STE11. The resulting fusion product, designated STE11M, added an 11-amino-acid peptide (EQKLISEEDLN) to the carboxyl terminus of the normal STE11 protein. The STE11M allele carried on a centromeric plasmid ( $\mathrm{pNC212)}$ was functional when tested for complementation of the mating defect caused by a ste11 deletion in the recipient strain (E929-6C-5).

We established that the monoclonal antibody Myc1-9E10 specifically detected the tagged STE11M protein produced in yeast by immunoblot analysis (data not shown). Because of the low abundance of the STE11M protein, this detection required enrichment of the protein by fractionation of significant amounts of extract. To simplify detection procedures and biochemical analyses described below, we overproduced the STE11M protein by placing the fusion gene under control of the GAL1,10 promoter (Fig. 1B, pNC245). An analogous GAL1,10-STE11 construction (Fig. 1B, pNC251) was made so that we would have a control for overproduction of STE 11 protein in a form that does not react with the Myc1-9E10 antibody. The overproduced STE11M protein was easily detected by immunoblot analysis of extracts fractionated by SDS-PAGE (Fig. 5, STE11M). Under the same conditions, no yeast protein was detected using the control extract (Fig. 5, STE11) or with extract from yeast with a complete ste11 deletion (Fig. 5, no STE11). The Myc1-9E10 antibodies also allowed specific detection of the STE11M protein by immunoprecipitation (see below).

\section{STE11 kinase domain mutation}

An in vitro immune complex assay would allow us to determine whether the STE11 gene product is a protein kinase (Collett and Erikson 1978). We wanted to have a catalytically inactive protein available as a negative control to establish whether any protein phosphorylation observed in this assay was due to STE11 activity. The lysine at STE11 position 444 corresponds to the conserved lysine that is essential for catalytic activity of known protein kinases (Hanks et al. 1988 and references therein). We constructed an arginine substitution mutation at lysine 444 of STE11M by site-directed mutagenesis. This mutation was chosen because an arginine substitution at the analogous position of other protein kinases has been shown to abolish kinase catalytic activity (Booher and Beach 1986; Celenza and Carlson 1989). Moreover, the arginine substitution is conservative and not expected to cause instability of the resulting protein.

The STE11M-R $\mathrm{R}^{444}$ protein was expressed from the 
Rhodes et al.

\begin{tabular}{|c|c|c|c|c|c|c|c|c|}
\hline $\begin{array}{l}\text { STE11 } \\
\text { STE7 } \\
\text { FUS3 } \\
\text { KSS1 }\end{array}$ & $\begin{array}{r}413 \\
189 \\
11 \\
11\end{array}$ & $\begin{array}{l}\text { KNWLKGACIG } \\
\text { QDLVQLGKIG } \\
\text { SDFQLKSLLG } \\
\text { SQYKLVDLIG } \\
-0---G\end{array}$ & $\begin{array}{c}\text { SGSFGSVYLG } \\
\text { AGNSGTVVKA } \\
\text { EGAYGVVCSA } \\
\text { EGAYGTVCSA } \\
\text {-G--G-V--- } \\
\text { I }\end{array}$ & $\begin{array}{l}\text { MNAHTGELMA } \\
\text { LHVPDSKIVA } \\
\text { THKPTGEIVA } \\
\text { IHKPSGIKVA } \\
-\cdots-- \text { - }\end{array}$ & $\begin{array}{l}\text { VKOVEIKNNN } \\
\text { KKTIPVEQNN } \\
\text { IKKIEPFDKP } \\
\text { IKKIQPFSKK } \\
\text {-KKII } \\
\text { II }\end{array}$ & $\begin{array}{l}\text { IGVPTDNNKQ } \\
\text { ST. . . IIN } \\
\text { LF. . . . . AL } \\
\text { LF. . . . VT }\end{array}$ & $\begin{array}{l}\text { ANSDENNEQE } \\
\text { QLVRELSIVK } \\
\text { RTLREIKIIK } \\
\text { RTIREIKLIR } \\
----E--1-- \\
\text { III }\end{array}$ & $\begin{array}{l}\text { EQQEKIEDVG } \\
\text { NVK. } \ldots \ldots \cdots \\
\text { HF. } \ldots \ldots \cdots \\
\text { YFH. } \ldots \ldots\end{array}$ \\
\hline $\begin{array}{l}\text { STE11 } \\
\text { STE7 } \\
\text { FUS3 } \\
\text { KSS1 }\end{array}$ & $\begin{array}{r}483 \\
247 \\
67 \\
68\end{array}$ & 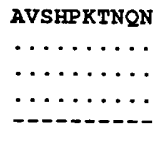 & $\begin{array}{l}\text { IHRKMVDALQ } \\
\ldots \ldots \ldots \cdots \\
\cdots \ldots \ldots \ldots \\
\ldots \ldots \ldots \\
\ldots \ldots\end{array}$ & $\begin{array}{l}\text { HEMRLIKELH } \\
\ldots \ldots \ldots \ldots \text { P } \\
\ldots \ldots \ldots \ldots \text { K } \\
\ldots \ldots \ldots \ldots \text {. }\end{array}$ & $\begin{array}{l}\text { HENIVTYYGA } \\
\text { HENIITFYGA } \\
\text { HENIITIFNI } \\
\text { HENIISILDK } \\
\text { HENI-OVI } \\
\text { IV }\end{array}$ & $\begin{array}{l}\text { SQEG. . . GNL } \\
\text { YYNQHINNEI } \\
\text { QRPDSFENFN } \\
\text { VRPVSIDKIN }\end{array}$ & $\begin{array}{l}\text { NIFLEYVPGG } \\
\text { IILMEYSDCG } \\
\text { EVYIIQELMQ } \\
\text { AVYLVELLME }\end{array}$ & $\begin{array}{l}\text { SVSSMLNNYG } \\
\text { SLDKILSVYK } \\
\text { T.DLHRVIST } \\
\text { T.DLQKVINN } \\
\mathrm{V}\end{array}$ \\
\hline $\begin{array}{l}\text { STE11 } \\
\text { STE7 } \\
\text { FUS3 } \\
\text { KSS1 }\end{array}$ & $\begin{array}{l}550 \\
288 \\
107 \\
108\end{array}$ & $\begin{array}{l}\text { P.......... } \\
\text { RFVQRGTVSS } \\
\text { QM........ } \\
\text { QNSGEST... }\end{array}$ & \begin{tabular}{c}
.... FEESL \\
KKTWFNELTI \\
$\ldots \ldots$ LSDDH \\
$\ldots \ldots$ LSDDH \\
\hdashline.--1
\end{tabular} & $\begin{array}{l}\text { ITNETRQILI } \\
\text { SKIAYGVLNG } \\
\text { IQYFIYQTLR } \\
\text { VQYFTYQIIR }\end{array}$ & $\begin{array}{l}\text { GVAYLHKKNI } \\
\text { IDHLYRQYKI } \\
\text { AVKVLHGSNV } \\
\text { ALKSIESAQV } \\
\text { VI }\end{array}$ & $\begin{array}{l}\text { IHRDIKGANI } \\
\text { IHRDIKPSNV } \\
\text { IHRDIKP SNL } \\
\text { IHRDIKP SNL } \\
\text { IHRD-K--N- }\end{array}$ & $\begin{array}{l}\text { LIDIKGCVKI } \\
\text { LINSKGQIKL } \\
\text { LINSNCDLKV } \\
\text { LLNSNCDLKV } \\
\text { L------K- }\end{array}$ & $\begin{array}{l}\text { TDFGISKKLS } \\
\text { CDFGVSKKLI } \\
\text { CDFGLARIID } \\
\text { CDFGLARCLA } \\
\text {-DFG----- } \\
\text { VII }\end{array}$ \\
\hline $\begin{array}{l}\text { STE11 } \\
\text { STE7 } \\
\text { FUS3 } \\
\text { KSS1 }\end{array}$ & $\begin{array}{l}358 \\
164 \\
170\end{array}$ & $\begin{array}{l}\text { PLNK . . . . . } \\
\text { NSIAD . . } \\
\text { ESAADNSEPT } \\
\text { SSSD . . SRE }\end{array}$ & $\begin{array}{l}\text {.KQNKRASLQ } \\
\text {.......TFV } \\
\text { GQQSGMTEYV } \\
\text { TLVGFMTEYV }\end{array}$ & $\begin{array}{l}\text { GSVFWMSPEV } \\
\text { GTSTYMSPER } \\
\text { ATRWYRAPEV } \\
\text { ATRWYRAPEI } \\
\text { III }\end{array}$ & $\begin{array}{l}\text { V. KQTATTAK } \\
\text { I.QGNVYSIK } \\
\text { MLTSAKYSRA } \\
\text { MLTFQEYTTA }\end{array}$ & $\begin{array}{c}\text { ADIWSTGCVV } \\
\text { GDVWSLGLMI } \\
\text { MDVWSCGCIL } \\
\text { MDIWSCGCIL } \\
\text {-D-WS-G--- } \\
\text { IX }\end{array}$ & $\begin{array}{l}\text { IEMFTGKHPF } \\
\text { IELVTGEFPL } \\
\text { AELFLRRPIF } \\
\text { AEMVSGKPLF } \\
\text {-E------ }\end{array}$ & $\begin{array}{l}\text { PDF ... . SQMQ } \\
\text { GGHN...DTP } \\
\text { PGRDYRHQLI } \\
\text { PGRDYHHQLW }\end{array}$ \\
\hline $\begin{array}{l}\text { STE11 } \\
\text { STE7 } \\
\text { FUS3 } \\
\text { KSS1 }\end{array}$ & $\begin{array}{l}665 \\
412 \\
234 \\
237\end{array}$ & $\begin{array}{l}\text { AIFKIGTNTT } \\
\text { DGILDLLQRI } \\
\text { LIFGIIGTPH } \\
\text { LILEVLGTPS } \\
-0 .-1\end{array}$ & $\begin{array}{l}\text { PE.IPSW.... } \\
\text { VN.EPSPRLP } \\
\text { SDNDLRCIES } \\
\text { FE.DFNQIKS }\end{array}$ & $\begin{array}{l}\text { KDRI . . . . } \\
\text { PRAREYIKSL } \\
\text { KRAKEYIANL }\end{array}$ & $\begin{array}{l}\text { PMY........ } \\
\text { PMRPAPLIPLET }\end{array}$ & $\begin{array}{l}\ldots \ldots \text {. ATSE } \\
\ldots \ldots \text { YSKE } \\
\text { MFPR. .VNPK } \\
\text { VWSKTDLNPD }\end{array}$ & $\begin{array}{r}\text { GKNFLRKAFE } \\
\text { MTDFVNRCCI } \\
\text { GIDLLRRMLV } \\
\text { MIDLLDKMLQ } \\
-0-1 \\
\text { XI }\end{array}$ & $\begin{array}{l}\text { LDYQYRPSAL } \\
\text { KNERERSSIH } \\
\text { FDPAKRITAK } \\
\text { FNPDKRISAA } \\
-----R----\end{array}$ \\
\hline $\begin{array}{l}\text { STE11 } \\
\text { STE7 } \\
\text { FUS3 } \\
\text { KSS1 }\end{array}$ & $\begin{array}{l}755 \\
459 \\
302 \\
306\end{array}$ & $\begin{array}{l}\text { CLHHDLIMK } \\
\text { ALEHPYLQT } \\
\text { ALRHPYLAM }\end{array}$ & $\begin{array}{l}\text { YVSPSKDDKF } \\
\text { YHDPNDEPEG } \\
\text { YHDP SDEPEY }\end{array}$ & $\begin{array}{l}\text { RHWCRKIKSK } \\
\text { EPIPPSFEEF } \\
\text { PPLNLDDEFW }\end{array}$ & $\begin{array}{l}\text { IXEDKRIKRE } \\
\text { DHHKKALTTK } \\
\text { KLDNKIMRPE }\end{array}$ & $\begin{array}{l}\text { ALDRAKLEKK } \\
\text { DLKKLIWNEI } \\
\text { EEEEVPIEML }\end{array}$ & $\begin{array}{l}\text { QSERSTH }{ }^{*} \\
\text { FS } \ldots \ldots \ldots \\
\text { KDMLYDELMK }\end{array}$ & $\begin{array}{l}\cdots \\
\ldots \ldots \\
\text { TME* }\end{array}$ \\
\hline
\end{tabular}

Figure 4. Alignment of the conserved protein kinase domain of STE11 with STE7, FUS3, and KSS1. Arabic numerals at the beginning of each line specify the amino acid position for each protein. Roman numerals beneath the sequences refer to subdomains of the protein kinase catalytic domain. The protein alignments and subdomain designations follow the criteria described in Hanks et al. (1988). Residues conserved among the four kinases are shown below the protein sequences. Those residues conserved in 62 of the 65 kinases compared in Hanks et al. (1988) are underlined. The sequences are STE11 (Fig. 2), STE7 (Teague et al. 1986), FUS3 (Elion et al. 1990), and KSS1 (Courchesne et al. 1989).

GAL1,10 promoter (pNC245-R444) in a ste11 deletion yeast strain (E929-6C-5). The yeast strain that expresses the STE11M-R $\mathrm{R}^{444}$ protein was not able to mate with an appropriate tester strain. We showed that the same amount of the STE11M (lane 5) and STE11M-R ${ }^{444}$ (lane 3) proteins were present in immune complexes from equivalent amounts of corresponding yeast extracts (Fig. $6 \mathrm{~A})$. No yeast protein was detected with the control immune complex performed with the untagged STE 11 protein (Fig. 6A, lane 1). These results confirm our expectations (1) that the arginine substitution protein is nonfunctional and (2) that it is stable.

\section{In vitro kinase assays}

Kinase assays were performed directly on immune complexes prior to fractionation and blot analysis of the immune complex proteins (see Fig. 6A). An autoradiograph of the immunoblot detected those proteins present in the immune complex that were ${ }^{32} \mathrm{P}$-phosphorylated during the kinase reaction. The autoradiograph shows that a number of phosphoproteins of varying size were generated during assays with all immune complexes (Fig. 6C, lanes 1, 3, and 5). Notably, phosphoproteins were present at the position of the STE11M or STE11M$\mathrm{R}^{444}$ proteins (Fig. 6C, lanes 5 and 3). There was no phosphoprotein at this position in the control with the untagged STE11 protein (Fig. 6C, lane 1). These results indicate that one or more contaminating kinases are nonspecifically adsorbed with the immune complexes and that both the STE11M and STE11M-R ${ }^{444}$ proteins serve as a substrate. Unfortunately, this result precludes any conclusion as to whether STE11 undergoes autophosphorylation. Nonetheless, the autoradiograph provided evidence for a STE11-dependent phosphorylation. A $78-\mathrm{kD}$ phosphoprotein (p78) was observed among the fractionated proteins from the immune complex with the functional STE11M but not from the complex with the mutant STE11M-R $\mathrm{R}^{444}$ protein (Fig. 6C, lanes 5 and 3).

It is most likely that the $\mathrm{p} 78$ phosphoprotein observed in this assay is an endogenous yeast protein that coprecipitates with STE11. First, it is present whether immune complexes are adsorbed with protein A-Sepharose beads or Staphlyococcus aureus cells (data not shown). Second, it does not appear to be a protein that cross-reacts with the Mycl-9E10 antibodies because it is not observed on immunoblots of yeast proteins (Figs. 5B and $6 \mathrm{~A})$. The presence of $\mathrm{p} 78$ has been inferred only from 


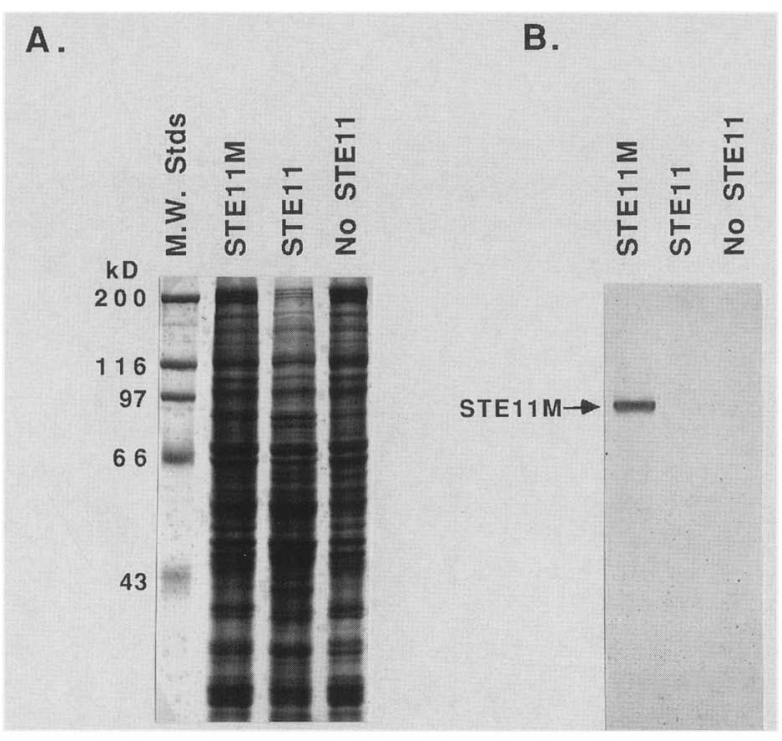

Figure 5. Immunological detection of the STE11M protein. $(A)$ Protein extract was prepared from a ste11 $\Delta$ strain (E929-6C-20) expressing STE11 (pNC251), STE11M (pNC245), or no STE11 (no plasmid). Each extract $(100 \mu \mathrm{g})$ was separated by SDS-gel electrophoresis and stained with Coomassie blue. Molecular weight standards are myosin, rabbit muscle phosphorylase b, bovine serum albumin, and hen egg white ovalbumin. $(B) \mathrm{Im}$ munoblot showing duplicates of samples in $A$. An arrow indicates the position of the STE11M protein.

its appearance as a phosphoprotein in the protein kinase assay. We were unable to detect p78 directly by using immune precipitates prepared from ${ }^{35} \mathrm{~S}$-labeled protein extracts or by silver stain procedures (data not shown). Therefore, we could not directly rule out the possibility that $\mathrm{p} 78$ is a yeast protein whose expression might be dependent on a functional STE11. For this reason additional experiments were performed to ensure that $\mathrm{p} 78$ was present in both the STE11M and STE11M-R ${ }^{444}$ extracts used for immune complex formation.

An immune complex assay was performed with STE11 extract that had been mixed with STE11M-R $\mathrm{R}^{444}$ extract. In this experiment, the STE11 extract would supply the $78-\mathrm{kD}$ polypeptide for coprecipitation with the nonfunctional but immune-reactive STE11M- $\mathrm{R}^{444}$ protein. Even though p78 was present in the mixed extract, it was not observed as a phosphoprotein with the nonfunctional STE11M-R ${ }^{444}$ immune complex kinase reaction (Fig. 6C, lane 2). The p78 phosphoprotein was observed in the control experiment where STE11 extract was mixed with STE11M extract (Fig. 6C, lane 4). This control provides evidence that the STE11 extract did not inadvertently inhibit phosphorylation of $\mathrm{p} 78$ in the mixing experiment.

A second set of experiments took advantage of the knowledge that there are no known genes whose expressions are STE11-dependent without also being dependent on the STE12 transcription factor (Errede et al. 1981; Fields et al. 1988). If we establish that p78 is present in a ste12 deletion strain, we can rule out the possibility that $\mathrm{p} 78$ expression is STE11-dependent with reasonable assurance. Immune complex kinase assays were done with extracts prepared from a ste12 deletion strain (E929-6C-7) expressing either the STE11M or the STE11M- $\mathrm{R}^{444}$ protein. Analysis of the fractionated immune complex proteins from these assays showed that equal amounts of the STE11M and the STE11M-R $\mathrm{R}^{444}$ proteins were present (Fig. 6B, lanes 1 and 2). The p78 phosphoprotein was observed for kinase reactions with the normal STE11M protein (Fig. 6D, lane 2). This result provides direct evidence that expression of $\mathrm{p} 78$ is not dependent on the STE12 transcription factor and, by inference, is independent of STE11 function. Yet p78 is not observed as a phosphoprotein for the immune complex assay with the kinase domain mutant STE $11 \mathrm{M}-\mathrm{R}^{444}$ protein (Fig. 6D, lane 1). It should be noted that the functional but untagged STE11 protein is expressed from the genome in the ste12 deletion strain used here. Therefore, $p 78$ is present in this extract regardless of the deduction that $\mathrm{p} 78$ expression is independent of STE11 function. By two independent methods, we have ensured the presence of $p 78$ but have not observed it as a phosphoprotein in kinase assays with the nonfunctional STE11M- $\mathrm{R}^{444}$ protein. This result establishes that phosphorylation of $\mathrm{p} 78$ is STE11-dependent and provides biochemical support for the view that STE11 is a protein kinase.

Protein kinases require a divalent cation for activity, and different kinases have different cation specificities. We investigated the divalent cation requirement for STE11 kinase activity. Parallel immune complex assays were performed in the presence of $5 \mathrm{~mm} \mathrm{Mg}{ }^{2+}, 5 \mathrm{mM}$ $\mathrm{Mn}^{2+}, 5 \mathrm{mM} \mathrm{Ca}^{2+}$, or $5 \mathrm{mM} \mathrm{Zn}^{+}$. Autoradiographs of the SDS-PAGE-fractionated proteins were compared visually for the presence and intensity of the signal that corresponds to the $78-\mathrm{kD}$ polypeptide (data not shown). $\mathrm{Mn}^{2+}$ appeared to be the preferred ion for kinase activity, followed by $\mathrm{Mg}^{2+}$ and $\mathrm{Zn}^{2+}$. $\mathrm{Ca}^{2+}$ did not support any STE11 catalytic activity.

\section{STE11 kinase activity is not regulated by pheromone induction and is not restricted to the mating- competent cell types}

The STE11 gene product is required for mating and for response to pheromone. It is not essential for other cellular processes because cells with a complete deletion of the gene are viable. Therefore, STE11 function appears to be very specific, and one might expect that its expression or activity could be restricted to the cell types and stages where its action is required. It has already been shown that STE11 mRNA is present in all cell types (Chaleff and Tatchell 1985). We have shown that STE11 mRNA is not increased in abundance when cells are treated with pheromone (Fig. 3B). These results indicate that STE11 expression is not regulated by the steadystate abundance of its mRNA.

Immune complex kinase assays were performed to investigate the possibility that STE11 kinase activity may be enhanced or repressed under pheromone-inducing 
Rhodes et al.

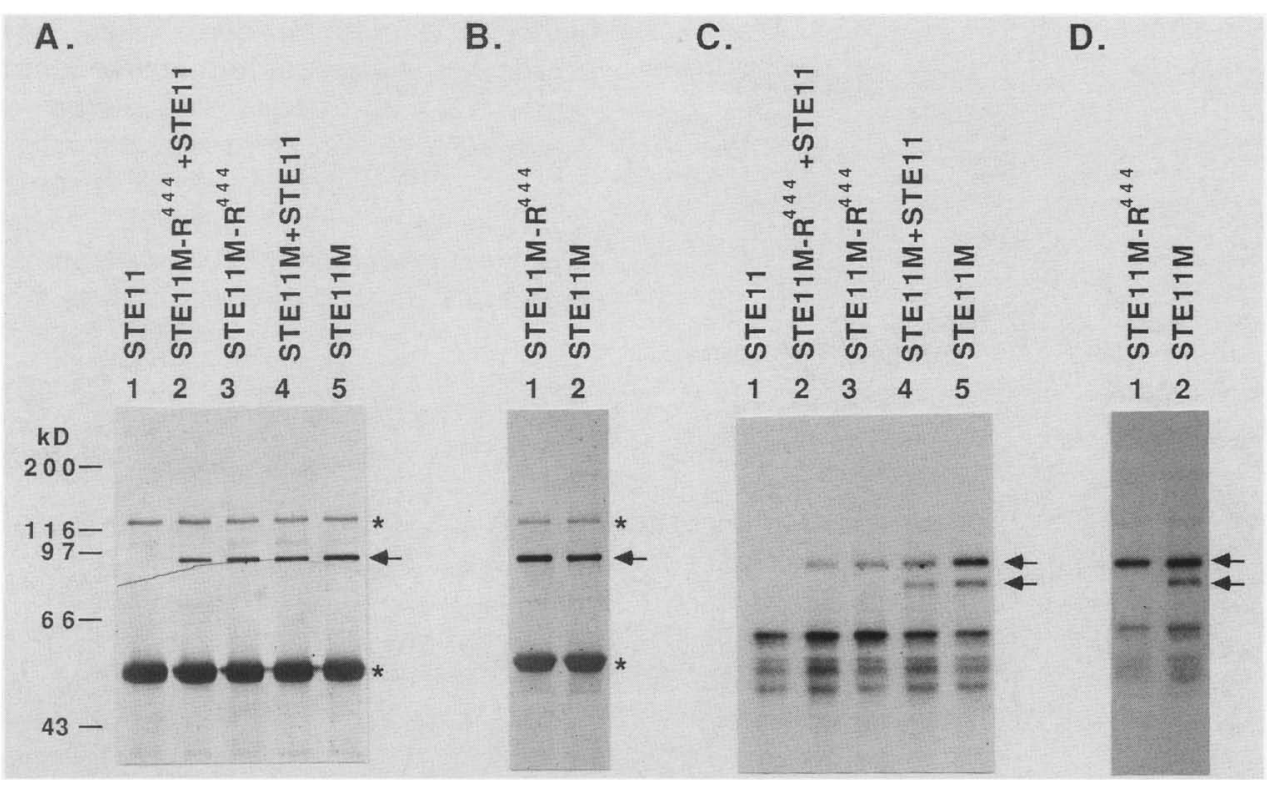

Figure 6. Immune complex kinase assays. $(A$ and $B)$ Immunoblots of immune complexes formed with Mycl-9E10 antibody and protein extracts as specified below. An arrow indicates the position of the STE11M and STE11M-R $\mathrm{R}^{444}$ proteins. Asterisks (*) show the positions of $\operatorname{IgG}(\mathrm{H}+\mathrm{L})$ and $\operatorname{IgG}(\mathrm{H}) .(C$ and $D)$ Autoradiographs of the immunoblots in $A$ and $B$, respectively. The upper arrow indicates the position of phosphorylated STE11M-R 444 and STE $11 \mathrm{M}$; the lower arrow indicates the position of the phosphorylated 78-kD protein p78. $(A$ and $C$ ) Protein extracts from transformed ste11 (E929-6C-5) strains as follows: (Lane 1) STE11 (pNC251); (lane 2) STE11 (pNC251) mixed with STE11M-R 444 (pNC245-R444); (lane 3) STE11M-R44 (pNC245- R444); (lane 4) STE11 (pNC251) mixed with STE11M (pNC245); (lane 5) STE11M (pNC245). (B and D) Protein extracts from transformed STE11 ${ }^{+}$ste12D (E929-6C-7) strains as follows: (lane 1) STE11M-R ${ }^{444}$ (pNC245-R444); (lane 2) STE11M (pNC245).

conditions. Immune complex assays were performed with extracts prepared from cultures treated with $\alpha$ factor. The same amount of STE11M was immunoprecipitated from each extract (Fig. 7A). Little difference in STE11M kinase activity was observed on the basis of its ability to phosphorylate p78 (Fig. 7B). This result suggests that STE11 kinase activity is not regulated by pheromone induction. This conclusion assumes that systems that may activate or inhibit STE 11 under conditions of pheromone induction do not become limiting with respect to the amount of STE11 produced under control of the GAL1,10 promoter.

We also investigated the possibility that STE11 activity as a kinase is restricted to mating-competent cell types. Extracts were prepared from mating-incompetent $a / \alpha$ diploid cells that overproduce the STE11M or STE11M- $\mathrm{R}^{444}$ protein. Both proteins were present in immune complexes from the respective diploid cell extracts $\langle$ Fig. $7 \mathrm{C}\rangle$. Autoradiographs of the proteins fractionated from the kinase assay showed that $\mathrm{p} 78$ was phosphorylated in reactions with the STE11M protein but not the inactive STE11MR ${ }^{444}$ protein (Fig. 7D). These results indicate that STE11 kinase activity is not absolutely restricted to the haploid cell type.

\section{STE11 kinase activity is required for its functions in vivo}

We wished to determine whether STE11 function as a kinase is required for both $G_{1}$ arrest and the transcriptional controls that are a prerequisite for mating. To make these tests, a MATa yeast strain with a complete deletion of the ste11 gene (E929-6C-28) was transformed with a centromeric plasmid that either does not express STE11 (pNC160), that expresses the normal STE11 protein (pNC193), or that expresses the catalytically inactive STE11- ${ }^{444}$ protein (pNC193-R444). The transformed strains were first compared for ability to mate by the standard patch test. The ste $11 \Delta$ transformed strain that did not express STE11 (E929-6C-28 pNC160) and the strain that produced the STE11- ${ }^{444}$ protein (E9296C-28 pNC193-R444) were completely mating defective (Table 1).

These three strains were then compared for their ability to become arrested in the $G_{1}$ phase by treatment with pheromone. The culture expressing the STE11 protein behaved toward pheromone in the characteristic fashion (Fig. 8). After a 2-hr exposure to pheromone, cells arrested at the $G_{1}$ stage of the cell cycle, as evidenced by the accumulation of unbudded cells. The culture accumulated unbudded cells $(80 \%)$ for $4 \mathrm{hr}$. After this time cells began to recover from pheromone-induced arrest, and numbers of unbudded cells in the cultures decreased. In contrast, the culture without any STE11 and the culture expressing the STE11- ${ }^{444}$ kinase mutation maintained the same low percentage of unbudded cells in the culture $(25-30 \%)$ throughout the time course of the experiment (Fig. 8).

We made use of two different reporter genes to determine whether the STE11- $\mathrm{R}^{444}$ kinase mutation would affect STE11-dependent transcription. The recipient strain used for these comparisons carries the CYC7-H2 


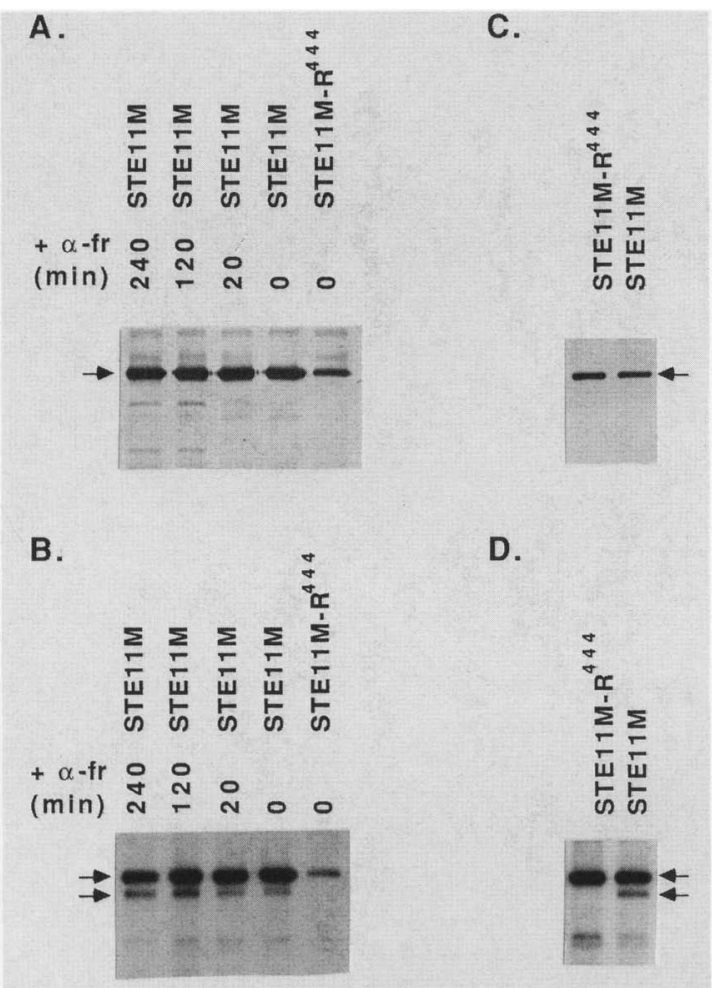

Figure 7. In vitro kinase activity of STE11 is not regulated by pheromone or cell type. $(A$ and $C)$ Immunoblots of immune complex kinase reactions performed with protein extracts as specified below. An arrow indicates the position of the STE11M and STE11M-R ${ }^{444}$ proteins. $(B$ and $D)$ Autoradiographs of immunoblots shown in $A$ and $C$, respectively. The upper arrow indicates the position of the phosphorylated STE $11 \mathrm{M}-\mathrm{R}^{444}$ and STE11M proteins; the lower arrow indicates the position of the phosphorylated $78-\mathrm{kD}$ protein, $\mathrm{p} 78 .(A$ and $B)$ Protein extracts from transformed ste11s (E929-6C-28) strains expressing STE1IM (pNC245) or STE11M-R ${ }^{444}$ (pNC245-R444) proteins. For pheromone induction, the culture expressing the STE11M protein (E929-6C-28, pNC245) was treated with $5 \mu \mathrm{M} \alpha$-factor, and protein extracts were prepared at indicated intervals after induction. $(C$ and $D)$ Protein extracts were from MATa/MATa diploid (E929-6C-32) strains expressing STE11M (pNC245) or STE1 IM-R ${ }^{444}$ (pNC245- $\mathrm{p}^{444}$ ) proteins.

gene as a reporter for basal levels of cell-type-specific gene expression and the FUS1-lacZ gene as a reporter for pheromone-inducible gene expression. The CYC7$H 2$ allele is an insertion of a Tyl element in the $5^{\prime}$-noncoding region of $C Y C 7$, which is the structural gene for iso-2-cytochrome $c$. The inserted Tyl element causes iso2-cytochrome $c$ expression to come under mating-type control and to be dependent on a functional STE11 product (Errede et al. 1981). The STE11-R $\mathrm{R}^{444}$ kinase mutation was defective in supporting basal levels of celltype-specific transcription as measured by iso-2-cytochrome $c$ production from the $\mathrm{CYC7}-\mathrm{H} 2$ reporter (Table 1). Expression of FUS1 in yeast is pheromone inducible, and this induction requires a functional STE11 product (McCaffrey et al. 1987). The 44-bp pheromoneinducible upstream activating sequence (UAS) from the
FUS1 gene was cloned upstream of the Escherichia coli lacZ gene, which encodes $\beta$-galactosidase. The STE11$\mathrm{R}^{444}$ kinase mutation was defective in supporting pheromone-inducible transcription as measured by $\beta$-galactosidase activity from the FUS1-lacZ reporter (Table 1). The results of the above experiments show that strains expressing the kinase domain mutant protein were defective for both pheromone-induced $G_{1}$ arrest and transcriptional activation functions. Because a single amino acid substitution that abolishes kinase activity is responsible for these defects, we conclude that STE11 kinase activity is crucial for each of these in vivo functions.

We also investigated the possibility that the ste11$R 444$ allele may have a dominant negative phenotype. A strain with a normal chromosomal copy of STE11 [E9296C-16) was transformed with the centromeric plasmid that overproduces the catalytically inactive STE11- $\mathrm{R}^{\mathbf{4 4 4}}$ protein (pNC245-R444). There was no interference with mating ability in the transformed strain even though the STE1 1- $\mathrm{R}^{444}$ protein was produced in large excess (E9296C-16 pNC245-R444; Table 1). The more sensitive and quantitative assay for pheromone-inducible expression of the FUS1-lacZ reporter was also applied. A fivefold reduction in the amount of $\beta$-galactosidase was observed with extracts from the strain that overproduces the nonfunctional STE11-R ${ }^{444}$ protein (E929-6C-16 pNC245$\mathrm{R} 444$ ) compared with the wild-type strain without overproduction of a STE11 protein (E929-6C-16). Therefore, it appears that the STE11-R ${ }^{444}$ protein may partially sequester components that become limiting for the mating response. Taken together, these data indicate that the ste11-R444 allele has only a weakly dominant negative phenotype.

\section{Discussion}

\section{Protein phosphorylation is required for signal transmission and response to pheromone}

The predicted protein sequence and biochemical evidence presented here support the view that STE11 is a protein kinase. On the basis of genetic criteria, STE11 function is required on the pheromone-induced signal pathway at a point after the $G$ protein and coincident with or prior to the STE12 transcription factor ( $\mathrm{Na}$ kayama et al. 1988; Dolan and Fields 1990). It follows that a STE11-dependent protein phosphorylation is required for signal transmission between these two components. There are two alternative models by which the STE11 kinase could fulfill this role. According to one model, the STE11 kinase could be transiently activated to transmit the induction signal by phosphorylation of a component on the pathway. In an alternative model, a STE11-dependent phosphorylation is a precondition for function or presence of a component that receives and transmits the pheromone-induced signal by a STE11-independent process. The immune complex assay we applied did not reveal a change in STE11 kinase activity under pheromone-inducing conditions. At face value, this result favors the second model for STE11 function 
Rhodes et al.

Table 1. Mating and transcriptional activation assays

\begin{tabular}{|c|c|c|c|c|c|c|}
\hline \multirow[b]{2}{*}{ Strain } & \multirow[b]{2}{*}{ Plasmid } & \multirow[b]{2}{*}{ Relevant genotype } & \multirow[b]{2}{*}{ Mating ${ }^{a}$} & \multirow[b]{2}{*}{ Iso-2-cytochrome $c^{b}$} & \multicolumn{2}{|c|}{$\beta$-Galactosidase ${ }^{c}$} \\
\hline & & & & & $-\alpha-\mathrm{fr}$ & $\overline{+\alpha-\mathrm{fr}}$ \\
\hline E929-6C-28 & none & ste11 & - & 5 & 10 & 11 \\
\hline E929-6C-28 & $\mathrm{pNCl} 60$ & ste11 & - & ND & ND & ND \\
\hline E929-6C-28 & $\mathrm{pNCl} 93$ & ste11 $1 \Delta$, pTE11+ & + & 18 & 3 & 1035 \\
\hline E929-6C-28 & pNC193-R444 & ste11 1 , pste11-R444 & - & 5 & 9 & 8 \\
\hline E929-6C-16 & none & $S T E 11^{+}$ & + & 20 & 64 & 4692 \\
\hline E929-6C-16 & pNC245 & $S T E 11^{+}, p G A L S T E 11 M$ & + & ND & 37 & 5821 \\
\hline E929-6C-16 & pNC245-R444 & STE $11^{+}$, pGALste $11 M-R 444$ & + & ND & 8 & 1367 \\
\hline
\end{tabular}

(ND) Not determined.

Mating competence $(+)$ or mating incompetence $(-)$ was determined by the patch test.

bOne unit corresponds to the amount of cytochrome $c$ produced in standard $c y c 1 \mathrm{CYC7}^{+}$yeast strains.

cUnits of $\beta$-galactosidase are $\left(1000 \times \Delta \mathrm{A}_{420}\right) /(\mathrm{min} \times \mathrm{mg}$ extract $)$.

on the response pathway. However, an in vitro kinase assay could be insensitive to in vivo regulatory mechanisms. Therefore, the question of whether the STE11 kinase transmits the pheromone-induced signal or is necessary to establish the function of some other signal transmission component remains unresolved.

Three other genes (STE7, KSS1, and FUS3) whose functions are implicated in the mating signal pathway have protein sequences predicting that they encode protein kinases. So far, STE1l is the only one for which biochemical evidence of a protein phosphorylation function has been provided. Each of the four kinases is likely to have a different role in the response pathway. On the basis of the phenotype of null mutants, it is clear that the activity of the KSS1 kinase is required for recovery from pheromone-induced $G_{1}$ arrest, whereas FUS3 has a predominant role in establishing pheromone-induced $G_{1}$ arrest. The STE7 and STE11 kinases are required for pheromone-inducible transcription, $G_{1}$ arrest, and mating. Even though the null mutant phenotypes are the same for the STE7 and STE11 kinases, it is unlikely that the two have redundant functions. First, the sequences of these two kinases are significantly different. This would exclude the possibility that they are isozymes or members of the same kinase subfamily. Second, we have found that the mating defect caused by a deletion of $s t e 7$ is not relieved by overproduction of the STE11 kinase and vice versa (N. Rhodes and $Z$. Zhou, unpubl.).

\section{Possible targets for STE11 kinase}

Resolution of the precise role that the STE1l kinase plays in the signal process will be aided by identification of its physiological targets and a knowledge of their biochemical functions. One possible physiological substrate of the STE11 kinase is the p78 protein that becomes phosphorylated in the immune complex kinase assay. Other protein kinases have been found to immunoprecipitate in complexes with physiologically relevant polypeptides. For example, the Cdc2 kinase immune precipitates in a complex with a functionally relevant substrate (Booher et al. 1989). If p78 is a relevant substrate, it represents an as-yet-unidentified component of the pheromone response pathway. The $78-\mathrm{kD}$ mobility is too slow for the predicted size of the $\alpha$-subunit (54 kD), $\beta$-subunit $(47 \mathrm{kD})$, or $\gamma$-subunit (13 kD) of G-protein, the STE7 protein kinase $(55 \mathrm{kD})$, or the FUS3 kinase $(40 \mathrm{kD}$ ) (Teague et al. 1986; Dietzel and Kurian 1987; Miyajima et al. 1987; Whiteway et al. 1989; Elion et al. 1990). The 78-kD mobility is faster than that observed for the STE12 $(116 \mathrm{kD})$ or STE5 $(115 \mathrm{kD})$ polypeptides (B. Errede, unpubl.; M. Hasson, R. Freedman, J. Schultz, and J. Thorner, in prep.). Even though none of the known components of the response pathway was implicated as a target of STE11 by the immune complex assay, some of these are logical candidates. For example, the STE12 transcription factor, the STE7 kinase, and the STE5 protein are each phosphoproteins (B. Errede, unpubl.; Z. Zhou, unpubl.; M. Hasson, R. Freedman, J. Schultz, and J. Thorner, in prep.).

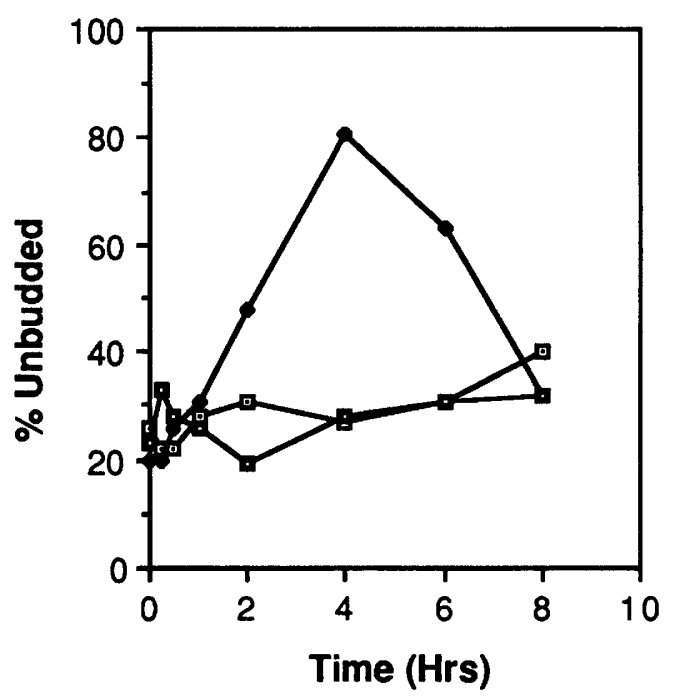

Figure 8. Pheromone-induced $\mathrm{G}_{1}$ arrest. Cultures of exponentially growing E929-6C-20 cells carrying plasmids pNC160 (), pNC193 $(-)$, or pNC193-R444 (-) were treated with $\alpha$-factor 15 $\mu \mathrm{M})$. Aliquots were removed at appropriate intervals, and the percentage of unbudded cells was determined. 


\section{Materials and methods}

\section{DNA sequence determinations}

The STE11 DNA sequence was determined by the chain-termination method according to "shotgun cloning" and sequencing procedures (Sanger et al. 1977, Bankier and Barrell 1983). DNA sequence data were assembled using DBSYSTEM programs on a VAX-11/780 computer (Staden 1982). In several regions, data for only one strand were obtained from the random cloning and sequencing strategy. Specific oligonucleotides were synthesized and used as sequencing primers for completion of the DNA sequence on both strands.

\section{Plasmids}

The STE11 centromeric plasmids pNC192 (Fig. 1B) and pNCl93 were constructed by cloning the $4.6-\mathrm{kb}$ BamHI-XhoI fragment (b) from pSTE11.1 (Fig. 1A) into the BamHI-Sall sites of the yeast shuttle vectors pNC160 and pNC161, respectively (Chaleff and Tatchell 1985; Rhodes et al. 1990). Fragment b includes the STE11 gene and promoter sequences. The pNC192 and pNC193 plasmids are identical except that the STE11 gene is in opposite orientations in relation to the M13 origin of replication on the vector. The two plasmids allow single-stranded DNA to be obtained for either the coding or noncoding strands of STE11. A construction was made with the GAL1,10 promoter to allow overproduction of the STE11 protein. A 685-bp EcoRI-BamHI fragment containing the GAL1,10 promoter from pBM150 was cloned into the EcoRI-BamHI site of pNCl60 (Johnston and Davis 1984; Rhodes et al. 1990). The HindIII site in the polylinker of the vector was destroyed by end-repair with Klenow polymerase and religation. The STE11 gene was cloned into the $B a m H I($ end-repaired)-SphI site of this vector as the $A c c I$ (end-repaired)-SphI fragment (c) (Fig. 1A). The resulting plasmid is designated pNC251 (Fig. 1B).

The plasmids pNC203 and pNC202 carry the ste11 $\Delta 6$ and ste11- $66::$ URA3 alleles, respectively. Construction of pNC203 involved the following steps. The STE11 3 '-flanking region was isolated as the $1-\mathrm{kb}$ PstI-ClaI(end-repaired) fragment (e) from pSTE11.1 (Fig. 1A) and cloned into the PstIAccI(end-repaired) sites in pUC119 (Vieiria and Messing 1987). This fragment was transferred as a SphI-BamHI fragment into the SphI-BamHI sites in pNC98 (Company and Errede 1987). The STE11 5'-flanking region was isolated as the $1.3-\mathrm{kb}$

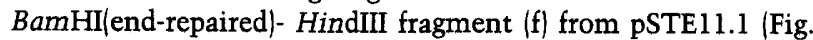
1A) and cloned into the HindIII(end-repaired)-EcoRI sites of the previous construction. The $1.2-\mathrm{kb}$ end-repaired-HindIII fragment containing the URA3 gene from pLG669-Z was isolated and cloned into the HpaI site of pNC203 to give pNC202 (Guarente and Ptashne 1981). All end-repair steps were accomplished by filling in of $5^{\prime}$ overhanging ends with Klenow polymerase.

The YRp7MAT $\alpha$ plasmid used for MAT gene replacement was provided by $\mathrm{K}$. Tatchell and has been described (Tatchell et al. 1981). The FUS1-lacZ reporter gene was provided by G. Ammerer on the integrating plasmid pGA1716. An oligonucleotide with XhoI-compatible ends and a sequence corresponding to the FUS1 UAS (nucleotide positions 3036-3074; Trueheart et al. 1987) was inserted into the XhoI site of pLG $\Delta 178$ (Guarente et al. 1984). To give the integrating plasmid pGA1716, sequences encompassing the $2-\mu \mathrm{m}$ origin of replication were deleted by digestion with HindIII and religation.

All plasmid constructions and DNA manipulations were performed as described (Maniatis et al. 1982). Enzymes were pur- chased from U.S. Biochemicals, New England Biolabs, and Bethesda Research Labs.

\section{Site-directed mutagenesis}

Two STE11 frameshift mutations were constructed. A single base pair insertion at STE11 nucleotide position 100 and a single base pair deletion of STE11 nucleotide position 377 were generated with mutagenic oligonucleotides STE11.26 and STE11.23, respectively (Table 2). pNC193 single-stranded DNA served as template for each of the mutagenesis reactions. The respective products of the mutagenesis were designated pNC193.100 and pNC193.377. The mutations were confirmed by DNA sequence determinations using the corresponding sequencing primers STE11.27 and STE11.18 (Table 2).

A fusion of the entire STE11-coding sequence with an oligonucleotide encoding the myc epitope tag (EQKLISEEDLN) was constructed by site-directed mutagenesis. The oligonucleotide used to insert the epitope-coding sequences (STE11.39; Table 2) includes the last four codons of STE11 (nucleotide positions 2255-2266), 11 codons for the peptide tag followed by the STE11 stop codon and 3 '-noncoding sequences (nucleotide positions 2267-2280). Single-stranded DNA from pNC192 served as the template for oligonucleotide-primed DNA synthesis. The insertion of the epitope-encoding sequences was confirmed by DNA sequence determination using oligonucleotide STE11.40 (Table 2) as the sequencing primer. The resulting construction is designated pNC212 (Fig. 1B). pNC245 carries the STE11-myc fusion under control of the GAL1,10 promoter. pNC245 was constructed by inserting the NcoI-SphI fragment (d) (Fig. 1A) from pNC212 into the NcoI-SphI site of pNC251 (Fig. 1B).

A lysine (amino acid position 444) to arginine substitution in the kinase catalytic domain of STEll was constructed by use of mutagenic oligonucleotide STE11.29 (Table 2). pNC193 singlestranded DNA served as template for the mutagenesis reaction. The product of the mutagenesis reaction was designated pNC193-R444. The substitution mutation was confirmed by DNA sequence determination using the oligonucleotide primer STE1 1.30 (Table 2). The substitution mutation under control of the GAL1,10 promoter (pNC245-R444) was constructed by cloning the 1.0-kb HindIII-NcoI fragment (g) (Fig. 1A) from pNC193-R444 into the HindIII-NcoI site of pNC245 (Fig. 1B).

Oligonucleotides (Table 2) for these studies were made by automated synthesis at the oligonucleotide facility in the Department of Pathology at the Univerity of North Carolina. Singlestranded template DNA was produced by the method of Kunkel (1985) with the addition of the helper phage M13K07 (Vieira and Messing 1987). Mutagenic oligonucleotides were annealed to the template, and second strand synthesis was performed as described (Zoller and Smith 1982). The resulting doublestranded DNA was transformed into E. coli strain $\mathrm{DH} 5 \alpha \mathrm{F}^{\prime}(\mathrm{Be}-$ thesda Research Laboratories). The desired mutations were identified by DNA sequence of random $E$. coli isolates. The phenotype of at least two independent isolates for each mutation was tested in yeast.

\section{Yeast genetic procedures}

The $\mathrm{LiCl}$ procedure was used for yeast transformations (Ito et al. 1983). Gene replacements were performed according to the method of Rothstein (1983). Unless specified, media and genetic procedures were as described in Sherman et al. (1979).

Pheromone inductions were performed by use of $\alpha$-factor (synthesized in the UNCCH-NIEHS Protein Chemistry Lab) at a final concentration of $5 \mu \mathrm{M}$ in medium that was buffered to pH 4.5 as described (Fink and Styles 1972). Pheromone-induced $\mathrm{G}_{1}$ arrest was assayed by using exponentially growing cells exposed to $\alpha$-factor. Aliquots were removed at appropriate in- 
Rhodes et al.

Table 2. Oligonucleotides

\begin{tabular}{llcc}
\hline Oligonucleotide & Sequence $\left(5^{\prime}-3^{\prime}\right)^{\mathbf{a}}$ & Strand & $\begin{array}{c}\text { Nucleotide } \\
\text { homology }\end{array}$ \\
\hline STE11.18 & AATATAACACAGTGC & - & $469-483$ \\
STE1 1.23 & ATTCACCTGTTAATCCGTTT & - & $368-389$ \\
STE 11.26 & TTCGTCTACCAGGTGATCTTA & - & $90-109$ \\
STE 11.27 & CTCTGCTGTTTGTGT & - & $125-139$ \\
STE 11.29 & CTCCACTTGCNTTACTGCC & - & $1438-1456$ \\
STE1 1.30 & TTGTTGTCTGTGGGAAC & - & $1478-1494$ \\
STE1 1.39 & GCACACATAATTGAGCAAAAGCTCATTTC & + & $2255-2280$ \\
STE 11.40 & TGAAGAGGACTTGAATTGAAAAAGGGCTAC & & \\
STE 11.75 & GGATTATCAATACAGGCC & + & $2200-2217$ \\
\hline
\end{tabular}

aMutagenic base(s) are underlined. (N) A mixture of the four nucleotides.

$\mathrm{b} /+\mid$ Coding strand of STE $11 ;|-|$ noncoding strand.

'Numbers indicate positions in the STE11 gene.

tervals and fixed in $5 \%$ formaldehyde, and cells were scored under a microscope as budded or unbudded. At least 200 individual cells were scored for each culture.

Mating competence was scored by the patch test (Sprague and Herskowitz 1981).

Yeast strains

The strain E929-6C (MATa cyc1, CYC7-H2, can1, leu2-3,112,

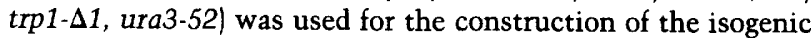
derivatives described below. The strains KZ8-1D (MATa cyc1-1, CYC7, his4, ura1) and KZ8-5C (MATa cyc1-1, CYC7, his4, ura1) were used as tester strains for determining mating phenotypes.

The ste11 deletion strain E929-6C-5 (ste11- $66::$ URA3) was constructed from E929-6C by use of the $2.6-\mathrm{kb} \mathrm{Xbal}$ fragment from pNC202 for gene replacement. A second ste11 deletion strain without the URA3 marker, E929-6C-20 (ste11- $\Delta 6$ ), was constructed from E929-6C-5 by use of the 1.4-kb XbaI fragment from pNC203 for gene replacement. The ste11- $66::$ URA3 allele in E929-6C-5 and ste11- $\Delta 6$ allele in E929-6C-20 were confirmed by Southern blot analysis. Strains with the FUS1-lacZ reporter gene, E929-6C-16 (STE11 + FUS1-lacZ) and E929-6C28 (ste11- $\triangle 6$ FUS1-lacZ) were constructed from E929-6C and E929-6C-20, respectively, by integration of pGAl716. The plasmid pGA1716 was linearized with ApaI to target its integration to the ura3-52 locus of the respective recipient strains. The diploid strain E929-6C-32 (MATa/MATa LYS2+/lys2) was made by crossing strain E929-6C to E929-6C-15 (MAT $\alpha$ lys2). First, an isogenic MAT $\alpha$ derivative of E929-6C was constructed by gene replacement using the 4.2-kb HindIII MAT $\alpha$ fragment from the plasmid YRp7MAT $\alpha$. A Lys ${ }^{-}$derivative of this MAT $\alpha$ strain was selected on $\alpha$-aminoadipate (Chattoo and Sherman 1979). The lesion causing the Lys ${ }^{-}$phenotype was shown to be a lys2 mutation by complementation analysis with a known lys2 strain. Construction of the ste12 deletion strain E929-6C-7 (STE11 ${ }^{+}$ste12- $11::$ URA3) has been described (Company and Errede 1988).

RNA analyses

RNA was prepared from cultures of E929-6C and E929-6C-20 in YPD medium. Cultures were grown to a density of $1 \times 10^{7}$ to $2 \times 10^{7}$ cells $/ \mathrm{ml}$ at $30^{\circ} \mathrm{C}$. RNA from pheromone-induced cells was prepared from E929-6C cultures in buffered YPD medium that had been exposed to $5 \mu \mathrm{M} \alpha$-factor for $2 \mathrm{hr}$ (Fink and Styles 1972). Total RNA was prepared according to the glass-bead lysis and extraction method (Broach et al. 1979).

Probe DNA for S1 protection analysis was prepared either with oligonucleotide STE11.75 or oligonucleotide STE11.18 (Table 2). The oligonucleotides were end-labeled using polynucleotide kinase and $\left[\gamma^{32} \mathrm{P}\right]$ ATP. The labeled primers were annealed to pNC193 template DNA and extended with Klenow polymerase. In the case of STE11.75, a 200-nucleotide probe was obtained by digestion with HindIII. In the case of STE11.18, a 1.1-kb nucleotide probe was obtained by digestion with $K p n I$. The probe DNAs were isolated from their corresponding mixtures after fractionation on a denaturing polyacrylamide gel (Dretzen et al. 1981). S1 nuclease reactions were performed according to established procedures (Greene and Struhl 1987). The size of the protected fragments was determined by electrophoresis on $8 \%$ denaturing polyacrylamide gels. A reference DNA sequence ladder was provided by DNA sequence reaction products obtained with pNC193 template DNA and the appropriate ${ }^{32} \mathrm{P}$-end-labeled primer (McGraw 1984).

\section{Preparation of yeast protein extracts}

Cultures requiring selection of plasmids were grown to mid-log phase in selective medium. Other cultures were grown in complete synthetic medium. Galactose $(2 \%)$ was used as the carbon source where overproduction of the STE 11 protein required induction of the GAL1,10 promoter. Pheromone ( $\alpha$-factor)-induced cultures were grown as described above with aliquots of the same culture taken at various intervals after treatment with $\alpha$-factor. Protein extracts were prepared as described by Company et al. (1988). A 40\% ammonium sulfate fraction was used for the experiments presented in this work. All protein concentrations were determined by use of the Bio-Rad protein assay reagent kit.

\section{Immunoprecipitations and kinase assays}

Immunoprecipitations and kinase assays were performed as described by Celenza and Carlson (1989). For our purpose, $500 \mu \mathrm{g}$ of protein extract was incubated with $10 \mu \mathrm{g}$ of the mouse monoclonal antibody Myc1-9E10 at $4^{\circ} \mathrm{C}$ (Evan et al. 1985). The antibody-protein complexes were precipitated by adsorption to Staphylococcus aureus cells (Sigma) or protein A-Sepharose beads (Sigma). The kinase assays were performed directly on the washed, adsorbed immune complexes by incubation with kinase assay buffer in the presence of $\left[\gamma^{32} \mathrm{P}\right] \mathrm{ATP}$. After the reaction, proteins were released from the adsorbed complex by boiling in SDS-PAGE buffer, fractionated by SDS-PAGE, and transferred to nitrocellulose. The nitrocellulose filters were subjected to immunoblot analysis for detection of immunoprecipitated proteins prior to autoradiography (see below). 


\section{Immunoblot analysis}

Whole-cell extracts or immune-precipitated proteins were fractionated on a $10 \%$ SDS-polyacrylamide gel and electroblotted onto nitrocellulose paper (Laemmli 1970; Towbin et al. 1979). The Mycl-9E10 antibody $(2 \mu \mathrm{g} / \mathrm{ml})$ was used to detect the electroblotted STE11M and STE11M-R ${ }^{444}$ proteins. The Promega Protoblot immunoblotting system with goat anti-mouse IgG conjugated to alkaline phosphatase $(0.1 \mu \mathrm{g} / \mathrm{ml})$ was used to detect the primary antibody by colorimetric methods. Immunoblotting and color development were performed according to procedures provided with the Promega Protoblot system.

\section{Assays for reporter gene products}

Enzymatic activity of $\beta$-galactosidase was measured by use of whole-cell protein extracts prepared $3 \mathrm{hr}$ after induction with $\alpha$-factor. Approximately $10^{8}$ cells were pelleted and washed with $1 \mathrm{ml}$ of $\mathrm{Z}$ buffer $\left(60 \mathrm{mM} \mathrm{Na}_{2} \mathrm{HPO}_{4}, 40 \mathrm{mM} \mathrm{NaH} \mathrm{PO}_{4}, 10\right.$ $\mathrm{mM} \mathrm{KCl}, 1 \mathrm{~mm} \mathrm{MgCl} 2,50 \mathrm{~mm}$ 2-mercaptoethanol) containing 1 mM phenylmethylsulfonyl fluoride (PMSF) (Miller 1982). The washed cells were suspended in $200 \mu$ l of $Z$ buffer with $1 \mathrm{mM}$ PMSF. Cells were lysed by vigorous vortexing with glass beads $\left(0.45-0.50 \mu \mathrm{m}\right.$ diameter) for $8 \mathrm{~min}$ at $4^{\circ} \mathrm{C}$. The supernatant from a 5-min centrifugation was removed to a clean tube, and protein concentration was determined. The $\beta$-galactosidase assays were performed by use of $10 \mu \mathrm{g}$ of protein extract in 120 $\mu \mathrm{l}$ of $\mathrm{Z}$ buffer containing $2.2 \mathrm{mM} O$-nitrophenyl- $\beta$-D-galactopyranoside. The change in absorbance at $420 \mathrm{~nm}$ with time was followed using a $\mathrm{V}_{\max }$ kinetic microtiter plate reader (Molecular Devices).

The relative amount of iso-2-cytochrome $c$ was determined spectroscopically from intact yeast cells that had been grown under derepressed conditions for cytochrome $c$ content (Errede et al. 1981).

\section{Acknowledgments}

The STE11 sequence data will appear in the EMBL/GenBank/ DDBJ Nucleotide Sequence Databases under the accession number X53431 Yeast STE11. We are grateful to K. Tatchell, G. Ammerer, and $C$. Price for critical reading of the manuscript. L.C. was a predoctoral trainee supported by National Institutes of Health grant T32-GM-07092. This research was supported by U.S. Public Health Service grants GM-30619 and GM-39852.

The publication costs of this article were defrayed in part by payment of page charges. This article must therefore be hereby marked "advertisement" in accordance with 18 USC section 1734 solely to indicate this fact.

\section{References}

Bankier, A.T. and B.G. Barrell. 1983. Techniques in nucleic acid biochemistry (ed. R.A. Flavell), pp. 1-34. Elsevier, Ireland.

Bender, A. and G.F. Sprague, Jr. 1986. Yeast peptide pheromones, a-factor and $\alpha$-factor, activate a common response mechanism in their target cells. Cell 47: 929-937.

Blinder, D., S. Bouvier, and D.D. Jenness. 1989. Constitutive mutants in the yeast pheromone response: Ordered function of the gene products. Cell 56: 479-486.

Booher, R.N., C.E. Alfa, J.S. Hyams, and D.H. Beach. 1989. The fission yeast $\mathrm{cdc} 2 / \mathrm{cdc} 13 / \mathrm{sucl}$ protein kinase: Regulation of catalytic activity and nuclear localization. Cell 58: 485497.

Booher, R. and D. Beach. 1986. Site-specific mutagenesis of $c d c 2$, a cell cycle control gene of the fission yeast Schizosaccharomyces pombe. Mol. Cell. Biol. 6: 3523-3530.
Broach, J.R., J.F. Atkins, C. McGill, and L. Chow. 1979. Identification and mapping of the transcriptional and translational products of the yeast plasmid, $2 \mu$ circle. Cell 16: 827-839.

Celenza, J.L. and M. Carlson. 1989. Mutational analysis of the Saccharomyces cerevisiae SNF1 protein kinase and evidence for functional interaction with the SNF4 protein. Mol. Cell. Biol. 9: 5034-5044.

Chaleff, D.T. and K. Tatchell. 1985. Molecular cloning and characterization of the STE7 and STE11 genes of Saccharomyces cerevisiae. Mol. Cell. Biol. 5: 1878-1886.

Chattoo, B.B. and F. Sherman. 1979. Selection of lys2 mutants of the yeast Saccharomyces cerevisiae by the utilization of $\alpha$-aminoadipate. Genetics 93: 51- 65.

Cigan, A.M. and T.F. Donahue. 1987. Sequence and structural features associated with translational initiator regions in yeast-A review. Gene 59: 1-18.

Cole, G.M., D.E. Stone, and S.I. Reed. 1990. Stoichiometry of G protein subunits affects the Saccharomyces cerevisiae mating pheromone signal transduction pathway. Mol. Cell. Biol. 10: 510-517.

Collett, M.S. and R.L. Erikson. 1978. Protein kinase activity associated with the avian sarcoma virus src gene product. Proc. Natl. Acad. Sci. 75: 2021-2024.

Company, M. and B. Errede. 1987. Cell type-dependent gene activation by yeast transposon Tyl involves multiple regulatory determinants. Mol. Cell. Biol. 7: 3205-3211.

. 1988. A Tyl cell type-specific regulatory sequence is a recognition element for a constitutive binding factor. Mol. Cell. Biol. 8: 5299-5309.

Company, M., C. Adler, and B. Errede. 1988. Identification of a Tyl regulatory sequence responsive to STE7 and STE12. Mol. Cell. Biol. 8: 2545-2554.

Courchesne, W.E., R. Kunisawa, and J. Thorner. 1989. A putative protein kinase overcomes pheromone-induced arrest of cell cycling in $S$. cerevisiae. Cell 58: 1107- 1119.

Cross, F., L.H. Hartwell, C. Jackson, and J.B. Konopka. 1988. Conjugation in Saccharomyces cerevisiae. Annu. Rev. Cell. Biol. 4: 429-457.

Dietzel, C. and J. Kurjan. 1987. The yeast SCG1 gene: A G -like $^{-}$ protein implicated in the a- and $\alpha$-factor response pathway. Cell 50: 1001-1010.

Dolan, J.W. and S. Fields. 1990. Overproduction of the yeast STE12 protein leads to constitutive transcriptional induction. Genes Dev. 4: 492-502.

Dolan, J.W., C. Kirkman, and S. Fields. 1989. The yeast STE12 protein binds to the DNA sequence mediating pheromone induction. Proc. Natl. Acad. Sci. 86: 5703-5707.

Dretzen, G., M. Bellard, P. Sassone-Corsi, and P. Chambon. 1981. A reliable method for the recovery of DNA fragments from agarose and acrylamide gels. Anal. Biochem. 112: 295-298.

Elion, E.A., P.L. Grisafi, and G.R. Fink. 1990. FUS3 encodes a $\mathrm{cdc} 2+/ \mathrm{CDC} 28$-related kinase required for the transition from mitosis into conjugation. Cell 60: 649-664.

Errede, B. and G. Ammerer. 1989. STE12, a protein involved in cell type-specific transcription and signal transduction in yeast, is part of protein-DNA complexes. Genes Dev. 3: $1349-1361$.

Errede, B. and T.S. Cardillo, G. Wever, and F. Sherman. 1981. Studies on transposable elements in yeast. I. ROAM mutations causing increased expression of yeast genes: Their activation by signals directed toward conjugation functions and their formation by insertion of Tyl repetitive elements. Cold Spring Harbor Symp. Quant. Biol. 45: 593-602.

Evan, G.I., G.K. Lewis, G. Ramsay, and J.M. Bishop. 1985. Isolation of monoclonal antibodies specific for human c-myc 
proto-oncogene product. Mol. Cell. Biol. 5: 3610-3616.

Fields, S., D.T. Chaleff, and G.F. Sprague, Jr. 1988. Yeast STE7, STE11, and STE12 genes are required for expression of cell type-specific genes. Mol. Cell. Biol. 8: 551-556.

Fink, G.R. and C.A. Styles. 1972. Curing of a killer factor in Saccharomyces cerevisiae. Proc. Natl. Acad. Sci. 69: 28462849.

Greene, J.M. and K. Struhl. 1987. S1 analysis of messenger RNA using single-stranded DNA probes. In Current protocols in molecular biology (ed. F.M. Ausubel, R. Brent, R.E. Kingston, D.D. Moore, J.G. Seidman, J.A. Smith, and K. Struhl), pp. 4.6.1-4.6.6. Greene/Wiley, New York.

Guarente, L. and M. Ptashne. 1981. Fusion of Escherichia coli lacZ to the cytochrome $c$ gene of Saccharomyces cerevisiae. Proc. Natl. Acad. Sci. 78: 2199-2203.

Guarente, L., B. Lalonde, P. Gifford, and E. Alani. 1984. Distinctly regulated tandem upstream activation sites mediate catabolite repression of the CYC1 gene of $S$. cerevisiae. Cell 36: $503-511$.

Hanks, S.K., A.M. Quin, and T. Hunter. 1988. The protein kinase family: Conserved features and deduced phylogeny of the catalytic domains. Science 241: 42-52.

Hartwell, L.H. 1980. Mutants of Saccharomyces cerevisiae unresponsive to cell division control by polypeptide mating hormone. J. Cell. Biol. 85: 811-822.

Herskowitz, I. 1989. A regulatory hierarchy for cell specialization in yeast. Nature 342: 749-757.

Ito, H., Y. Fukuda, K. Murata, and A. Kimura. 1983. Transformation of intact yeast cells treated with alkali cations. $I$. Bacteriol. 153: 163-168.

Jahng, K., J. Ferguson, and S.I. Reed. 1988. Mutations in a gene encoding the $\alpha$ subunit of a Saccharomyces cerevisiae G protein indicate a role in mating pheromone signaling. Mol. Cell. Biol. 8: 2484-2493.

Johnston, M. and R.W. Davis. 1984. Sequences that regulate the divergent GAL1-GAL10 promoter in Saccharomyces cerevisiae. Mol. Cell. Biol. 4: 1440-1448.

Kunkel, T.A. 1985. Rapid and efficient site-specific mutagenesis without phenotypic selection. Proc. Natl. Acad. Sci. 82: 488-492.

Laemmli, U.K. 1970. Cleavage of structural proteins during the assembly of the head of bacteriophage T4. Nature 227: 680685.

Langford, C.J. and D. Gallwitz. 1983. Evidence for an introncontained sequence required for the splicing of yeast RNA polymerase II transcripts. Cell 33: 519-527.

Maniatis, T., E.F. Fritsch, and J. Sambrook. 1982. Molecular cloning: A laboratory manual. Cold Spring Harbor Laboratory, Cold Spring Harbor, New York.

McCaffrey, G., F.J. Clay, K. Kelsay, and G.F. Sprague, Jr. 1987. Identification and regulation of a gene required for cell fusing during mating of the yeast Saccharomyces cerevisiae. Mol. Cell. Biol. 7: 2680-2690.

McGraw, R.A. III. 1984. Dideoxy DNA sequencing with end-labelled oligonucleotide primers. Anal. Biochem. 143: 298303.

Miller, J. 1972. Experiments in molecular genetics. Cold Spring Harbor Laboratory, Cold Spring Harbor, New York.

Miyajima, I., M. Nakafuku, N. Nakayama, C. Brenner, A. Miyajima, K. Kaibuchi, K. Arai, Y. Kaziro, and K. Matsumoto. 1987. GPA1, a haploid-specific essential gene, encodes a yeast homolog of mammalian $G$ protein which may be involved in mating factor signal transduction. Cell 50: $1011-1019$.

Munro, S. and H.R.B. Pelham. 1987. A C-terminal signal prevents secretion of luminal ER proteins. Cell 48: 899-907.
Nakayama, N., A. Miyajima, and K. Arai. 1987. Common signal transduction system shared by STE2 and STE3 in haploid cells of Saccharomyces cerevisiae: Autocrine cell cycle arrest results from forced expression of STE2. EMBO $I$. 6: $249-254$.

Nakayama, N., Y. Kaziro, K. Arai, and K. Matsumoto. 1988. Role of STE genes in the mating factor signaling pathway mediated by GPAl in Saccharomyces cerevisiae. Mol. Cell. Biol. 8: 3777-3783.

Nomoto, S., N. Nakayama, K. Arai, and K. Matsumoto. 1990. Regulation of the yeast pheromone response pathway by $\mathrm{G}$ protein subunits. EMBO I. 9: 691-696.

Pearson, W.R. and D.J. Lipman. 1988. Improved tools for biological sequence comparison. Proc. Natl. Acad. Sci. 85: 24442448.

Rhodes, N., M. Company, and B. Errede. 1990. A yeast-Escherichia coli shuttle vector containing the M13 origin of replication. Plasmid 23: 159-162.

Rothstein, R.J. 1983. One-step gene disruption in yeast. Methods Enzymol. 101: 202-211.

Sanger, F., S. Nicklen, and A.R. Coulson. 1977. DNA sequencing with chain-terminating inhibitors. Proc. Natl. Acad. Sci. 74: 5463-5467.

Sherman, F., G.R. Fink, and J.B. Hicks. 1979. Methods in yeast genetics. Cold Spring Harbor Laboratory, Cold Spring Harbor, New York.

Sprague, G.F., Ir. and I. Herskowitz. 1981. Control of yeast cell type by the mating type locus. I. Identification and control of expression of the a-specific gene BAR1. I. Mol. Biol. 153: 305-321.

Staden, R. 1982. Automation of the computer handling of gel reading data produced by the shotgun method of DNA sequencing. Nucleic Acids Res. 10: 4731-4751.

Tatchell, K., K.A. Nasmyth, B.D. Hall, C. Astell, and M. Smith. 1981. In vitro mutation analysis of the mating-type locus in yeast. Cell 27: 25-35.

Teague, M.A., D.T. Chaleff, and B. Errede. 1986. Nucleotide sequence of the yeast regulatory gene STE7 predicts a protein homologous to protein kinases. Proc. Natl. Acad. Sci. 83: $7371-7375$.

Towbin, H., T. Staehelin, and J. Gordon. 1979. Electrophoretic transfer of proteins from polyacrylamide gels to nitrocellulose sheets: Procedure and some applications. Proc. Natl. Acad. Sci. 76: 4350-4354.

Trueheart, J., J.D. Boeke, and G.R. Fink. 1987. Two genes required for cell fusion during yeast conjugation: Evidence for a pheromone-induced surface protein. Mol. Cell. Biol. 7: 2316-2328.

Vieira, J. and J. Messing. 1987. Production of single-stranded plasmid DNA. Methods Enzymol. 153: 3-11.

Whiteway, M., L. Hougan, D. Dignard, D.Y. Thomas, L. Bell, G.C. Saari, F.J. Grant, P. O'Hara, and V.L. MacKay. 1989. The STE4 and STE18 genes of yeast encode potential $\beta$ and $\gamma$ subunits of the mating factor receptor-coupled $G$ protein. Cell 56: 467-477.

Whiteway, M., L. Hougan, and D.Y. Thomas. 1990. Overexpression of the STE4 gene leads to mating response in haploid Saccharomyces cerevisiae. Mol. Cell. Biol. 10: 217222.

Zaret, K.S. and F. Sherman. 1982. DNA sequence required for efficient transcription termination in yeast. Cell 28: 563573.

Zoller, M.J. and M. Smith. 1982. Oligonucleotide-directed mutagenesis using M13-derived vectors: An efficient and general procedure for the production of point mutations in any fragment of DNA. Nucleic Acids Res. 10: 6487-6500. 


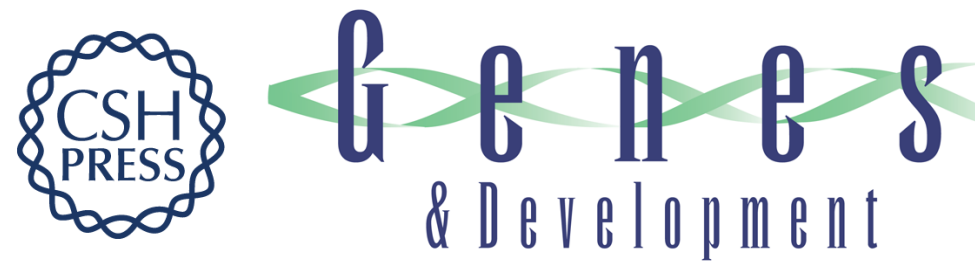

\section{STE11 is a protein kinase required for cell-type-specific transcription and signal transduction in yeast.}

N Rhodes, L Connell and B Errede

Genes Dev. 1990, 4:

Access the most recent version at doi:10.1101/gad.4.11.1862

References This article cites 59 articles, 31 of which can be accessed free at:

http://genesdev.cshlp.org/content/4/11/1862.full.html\#ref-list-1

License

Email Alerting

Service

Receive free email alerts when new articles cite this article - sign up in the box at the top right corner of the article or click here.

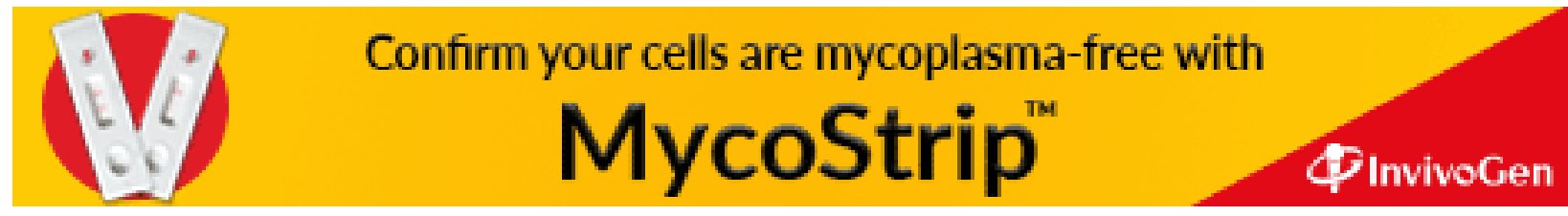

